

\title{
Entrepreneurial Orientation and SME Performance: The Serial Mediating Effects of Access to Finance and Competitive Advantage
}

Syamsuriana Sidek, Mohd Rosli Mohamad and Wan Mohd Nazdrol Wan Nasir

To Link this Article: http://dx.doi.org/10.6007/IJARBSS/v9-i9/6271

DOI: $10.6007 /$ IJARBSS/v9-i9/6271

Received: 22 June 2019, Revised: 24 July 2019, Accepted: 30 August 2019

Published Online: 24 September 2019

In-Text Citation: (Sidek, Mohamad, \& Nasir, 2019)

To Cite this Article: Sidek, S., Mohamad, M. R., \& Nasir, W. M. N. W. (2019). Entrepreneurial Orientation and SME Performance: The Serial Mediating Effects of Access to Finance and Competitive Advantage. International Journal of Academic Research in Business and Social Sciences, 9(9), 81-100.

\section{Copyright: (C) 2019 The Author(s)}

Published by Human Resource Management Academic Research Society (www.hrmars.com)

This article is published under the Creative Commons Attribution (CC BY 4.0) license. Anyone may reproduce, distribute, translate and create derivative works of this article (for both commercial and non-commercial purposes), subject to full attribution to the original publication and authors. The full terms of this license may be seen at: http://creativecommons.org/licences/by/4.0/legalcode

Vol. 9, No. 9, 2019, Pg. 81 - 100

Full Terms \& Conditions of access and use can be found at http://hrmars.com/index.php/pages/detail/publication-ethics 




\title{
Entrepreneurial Orientation and SME Performance: The Serial Mediating Effects of Access to Finance and Competitive Advantage
}

\author{
Syamsuriana Sidek, Mohd Rosli Mohamad and Wan Mohd \\ Nazdrol Wan Nasir \\ Faculty of Entrepreneurship and Business, Universiti Malaysia Kelantan, Malaysia \\ Email: suriana@umk.edu.my; mrosli@umk.edu.my;nazdrol@umk.edu.my
}

\begin{abstract}
Development of Small and Medium Enterprises (SMEs) is widely recognised as crucial sectors to the growth of internal market as well as international market. Even so, the statistics showed that they depicted of high mortality rate predominantly during their first three years of start-up phase. Recognizing the requisite study to find out the causes behind this issue, numerous prior scholars have done the research about determinants of SME performance. Consequently, previous works always related performance with Resource-based view (RBV) theory, whereby, resources and capabilities in firm level is significant to retain competitive advantage and sustain performance. Motivated to RBV theory, this research purposes to examine the factors of business performance and serial mediating effect by mapping entrepreneurial orientation as capability and access to external financial as resource which could generate competitive advantage and eventually increase SME performance. A data of 284 SMEs was proportionate stratified randomly selected analysed by using Structural Equation Model (AMOS-SEM). Resulting this, this current study highlighted that the relationship between entrepreneurial orientation and SME performance was partially serial mediated by access to external finance and competitive advantage. The study stimuli the authorities such as policy makers and support systems including entrepreneurs, that entrepreneurial orientation and access to external financial resource by SME would offer competitive advantage in the firm which to conclude enhance business performance. Upcoming studies may expand this research via adding and probing either internal or external critical factors that significant to the variant of SME performance.
\end{abstract}

Keywords: Entrepreneurial Orientation, Business, Performance, Access to Finance, Competitive Advantage, Mediating, Structural Model.

\section{Introduction}

Undeniably, Small and Medium Enterprises (SMEs) play a crucial role of local as well as country economic development in both high-income and low-income economies (Schans, 2012). To date, they were believed gave significant contribution to the Gross Domestic Product (GDP), poverty alleviation, equal distribution of income, tax revenues, export 
performance, domestic savings, employment creation and also entrepreneurial development of an economy (Blackburn et al., 2013; Tambunan, 2011).

Moreover, SMEs existence scattered across the world leads to statistical recorded of over 90 per cent form global economic expansion (Ayyagari, Demirguc-Kunt, \& Maksimovic, 2011). This glowing contributions also occurring in Malaysia, where SMEs accounted 98.5 per cent of total firm establishment (SME Annual Report, 2017; SME Corporation Malaysia, 2019). Similarly, Malaysian SMEs act as driver of development to domestic economy since they continually being the highest contribution to the annual GDP by key economic activity, specifically recorder 36.6 per cent in 2016 and predicted to surpass 40 per cent by the end of 2018 (SME Corporation Malaysia, 2019). Not only that, they also presented as significant contributor to the national rate of employment, which they recorded employed about 5.65 million out of 7.0 million total employees specifying 80.7 per cent based on economic censuses conducted 2016 (DOS Malaysia, 2018).

\section{Issues of the Study}

Adjudicating from the statistical, SMEs are seen as essential economics indicator towards country growth. Nevertheless, some of entrepreneurs are still struggling while some others had to fold up. In reality, this is truth of a cruel world out there for them (Jeff, 2017). Accordance on US Small Business Administration (2017) exposed that the survival rate of a firm after 10 years establishment was only 34 per cent. This explains that the failure rate of firm within 10 years indicates about 66 per cent was quite terrible. Furthermore, mortality rate of SMEs in US for first year establishment recorded 24 per cent and double for next second year (48\%) (Jarvis, 2015).

This worried situation was not exception to Malaysian SMEs. Even though they monopoly the number of total firm establishment and financing facilities offered more than 96 per cent (SME Annual Report, 2017/2018), only 18 per cent registered companies were able to sustain and had succeeded after five years (Bernama, 2017). Accordingly, the study to find out the reason behind this chaos situation is needed to be considered by the researchers especially in Malaysia context.

Recognizing the important of this nature of studies, many prior works on determinants of business performance had been completed. Subsequently, many internal and external factors related to performance had been unearthing. Meanwhile, business performance concept is always being linked to Resource Based-View (RBV) theory framework. This theory enlightened the roles of valuable resources and capabilities in the firm can be a source of sustainable for competitive advantages (Barney, 1986; Mahoney, 1995; Wernerfelt, 1984) and finally improved performance.

Judging this, entrepreneurial orientation can be observed as one of the capability in the firm (Lorenzo, Rubio, \& Garcés, 2018) and financial strength could be treated as company valuable resources. Then, these resources and capabilities are becoming key sources of building competitive advantage strategy (Castellaneta, 2016), while, competitive advantage is seen as a catalyst of better performance (Vance \& De Angelo, 2007). This connection can be draw as serial mediation which brings the meaning of including more than one factor in linking the independent variable and dependent variable (Hayes, 2013).

Therefore, as motivation and advance prior studies, this research intended to test relationship that consider access to finance and competitive advantage as serial mediating 
variables in between entrepreneurial orientation and SME performance. Hence, the main objectives of this study are:

1. To examine the relationship between entrepreneurial orientation and performance of SME.

2. To determine the serial mediation effect of access to finance and competitive advantage in the relationship between entrepreneurial orientation and SME performance.

\section{Conceptual Framework and Hypotheses Development}

As mentioned in previous part, business performance is always related with RBV theory. This theory assumed the capability and resources possessed by a firm are the primary determinants of organizational performance. Based on this theory, the current study linked the entrepreneurial orientation as firm capability and access to finance as internal resource to generate competitive advantage and competitive advantage eventually may promise well performance. Hence, this section was discussed the chronology of hypotheses formulation. The conceptual framework of this study was develop based RBV theory and mainly assimilated the prior studies by Fatoki (2012) and Rosli and Norshafizah (2013).

\section{Entrepreneurial Orientation and Business Performance}

The positive significant impact of entrepreneurial orientation on business performance has get attention by many prior works since entrepreneurial orientation concept has been developed by Miller (1983). As noted by Avlonitis and Salavou (2007) entrepreneurial orientation at firm level undertaking the greater growth and higher profitability. Whereas, Moreno and Casillas (2008) affirmed that entrepreneurial orientation was significant positive in encouraging innovativeness of production, latter, offer important benefits to business development. Likewise, Rauch and Frese (2009) found that the variation of organizational with entrepreneurial orientation can increase 24 per cent their business performance. Hence, the main hypothesis of this study was expressed as:

H1: Entrepreneurial orientation is positive significant influence to SME performance.

However, entrepreneurial orientation was recognised as multidimensional constructs following early scholar such as Miller (1983) and Covin and Slevin (1989). As a result, this study concerned three dimensions of entrepreneurial orientation which is innovativeness, risk taking and aggressive competitiveness in line with Andersén (2010), Casillas et al. (2011), Hermann et al. (2010), Hansen et al. (2011), Knight (1997), Kellermanns and Eddleston (2006), Moreno and Casillas (2008), Weismeier-Sammer (2011) and Zahra and Covin (1995). As mentioned by Davis et al. (2010), the entrepreneur with high of entrepreneurial orientation in term of favouring innovative activities, ready to take risk and demonstrate high degree of being ahead compared their business rivals have positive relationship with business performance. Thus, the sub-hypotheses of this study were formulated as follow:

H1a: The innovativeness is positive significant influence to SME performance.

H1b: The risk taking is positive significant influence to SME performance.

H1c: The aggressive competitiveness is positive significant influence to SME performance. 


\section{Access to Finance and Competitive Advantage as Mediators}

RBV theory is the most appropriate theory used to explain business performance. This theory clarified the firm that deployed resource and capability possibly will cherish competitive advantage (see Barney, 1986; Porter, 1980). Based on this statement, this study underlined the roles of entrepreneurial orientation as capability and access to finance as resource which support competitive advantage strategies in the firm. Competitive advantage in numerous studies described to greater performance (see Awino \& Kariuki, 2012; Barrett, Davidson, Prabhu, \& Vargo, 2015; Chahal \& Bakshi, 2015; Suhail \& Mushtaq, 2016).

High of entrepreneurial orientation and access to finance in the firm level supposedly could bring many opportunities in order firm to have better access to external financial support. To Fatoki (2012), the firms that focus on strategic entrepreneurial orientation were able to have opportunity access of debt capital since a good relationship with the loan supply. Likewise, Li, Zhao, Tan and Liu (2008) verified that innovated firms, risk taking and aggressive firms lead to better accessing of external financial support and more advance, also able to seek new opportunities. While, sufficient access to finance could support the competitive advantage strategies in the firm (Castellaneta, 2016; Henard \& McFadyen, 2012; Schilke, 2014). Porter (1980) has discussed that strong point in the organization finally fall into strategies either cost leadership, differentiation and focus.

Thus, judging from these arguments, this study predicted that the significant and positive relationship among entrepreneurial orientation, access to finance, competitive advantage and business performance was exist. Hence, second hypothesis was developed as:

H2: $\quad$ The relationship between entrepreneurial orientation and SME performance is serially mediated by the access to finance and competitive advantage.

Again, as a consequence dimensions of entrepreneurial orientation, sub-hypotheses were draw as follow:

H2a: The relationship between innovativeness and SME performance is serially mediated by the access to finance and competitive advantage.

$\mathbf{H} \mathbf{2 b}$ : The relationship between risk taking and SME performance is serially mediated by the access to finance and competitive advantage.

H2c: The relationship between aggressive competitiveness and SME performance is serially mediated by the access to finance and competitive advantage.

\section{Research Methodology}

The research methodology part was discussing about how the data has been obtained, the instrumental development and several procedures for analysing data.

\section{Data Collection and Sample}

This research employed primary data which is multi-methods data collection approach since data comes from various sources such as self-administered questionnaire, mail questionnaire and also face to face survey. Moreover, multi-sources of data collected able to reduce the bias of the data which indirectly leads to rigor in research, have great degree of similarity and ensure goodness of the data collected (Sekaran \& Bougie, 2013). The research instrument used in this study is questionnaire where it was initially deep constructed adapted by prior works and comprehensively revised several time. 
Moreover, to be practically used in Malaysia environment, this questionnaire is provided into two languages which are English and Malays. Besides that, the sample of this study was SMEs in East Coast Region of Malaysia since it is impossible for the researchers to cover up all SMEs in Malaysia. Therefore, this study downloaded the sampling frame from website of SMEs Corporation Malaysia (2015) available at http://www.smecorp.gov.my/index.php/en/guides/2015-12-21-10-49-38/list-of-companies.

Resulting this, the present study decided to employ proportionate stratified random sampling which the number of sampling units drawn from each stratum is in proportion to the population size of that stratum. This technique is most suitable since it most efficient among all probability designs, offers greater data accuracy, more affordable since it often requires a smaller sample in each subgroup (strata), decrease of unrepresentative sample and obtains sufficient sample points to support a separate analysis of any stratum (Cooper \& Schindler, 2014; Sekaran \& Bougie, 2013). Moreover, this technique also fulfils the SEMAMOS assumption of data normality which enables the study to proceed with covariance based analysis to meet all research objectives via hypotheses testing.

Consequently, the sample in this study was proportionated into states: Kelantan, Terengganu and Pahang and types of sectors as in Table 1. Meanwhile, the total size of sample is predicted 382 based on determining table of sample size as formulated by Krejcie and Morgan (1970). However, only 284 samples were considered by the study due to some constraints of the study. Even so, these 284 samples were acceptable to use Structural Equation Modeling (SEM), sufficient enough as per required by Kenny, Kaniskan, \& McCoach (2011) where 200 sample size was seen as a goal for SEM researchers.

Table 1. Proportionate stratified random sampling according state and types of sector

\begin{tabular}{|c|c|c|c|c|}
\hline & & \multicolumn{3}{|c|}{ Stratum } \\
\hline & & Kelantan & Terengganu & Pahang \\
\hline $\begin{array}{l}\text { Number of } \\
\text { Elements }\end{array}$ & 113,515 & 46,618 & 29,324 & 37,573 \\
\hline Stratum & $\begin{array}{c}\text { Percentage } \\
\text { (\%) of Elements }\end{array}$ & \multicolumn{3}{|c|}{ Number of Subjects in the Sample } \\
\hline Services & 89.2 & 140 & 88 & 112 \\
\hline Manufacturing & 5.3 & 8 & 5 & 7 \\
\hline Construction & 4.3 & 7 & 4 & 6 \\
\hline Agriculture & 1.1 & 2 & 2 & 1 \\
\hline $\begin{array}{l}\text { Mining \& } \\
\text { Quarrying }\end{array}$ & 0.1 & 0 & 0 & 0 \\
\hline Total & 100 & 157 & 99 & 126 \\
\hline Total Sample & & \multicolumn{3}{|c|}{382} \\
\hline
\end{tabular}

Note: Number and percentage of elements adopted from SME Annual Report (2017).

Source: Developed by researchers for this study. 


\section{Measurement}

The dependent variable for this study was SME performance (BP) which is constructed by 9 items. The items are sales (BP1), market share (BP2), customer satisfaction on product or services (BP3), product quality level (BP4), profitability level (BP5), production level (BP6), number of employees (BP7), number of new customer (BP8) and level of income (BP9) were mainly modified from Ar and Baki (2011), Gathenya et al. (2011) and Koe (2013). All items are subjectively fixed to five-point of Likert scale ( $1=$ significantly lower, $3=$ unchanged and $5=$ significantly higher).

In the meantime, the independent variable in this study was entrepreneurial orientation. However, since entrepreneurial orientation comes from multi-dimensional constructs (see Covin, Green, \& Slevin, 2006; Lumpkin \& Dess, 2001), this study focused on three dimensions which are innovativeness (INNO), risk taking (RISK) and aggressive competitiveness (AC). All dimensions are measured by five items following to Covin and Slevin (1989), Kreiser et al. (2002), Messeghem (2003), Miller (1983), Tarabishy, Solomon, Fernald, and Saghkin (2005), as well Wiklund and Shepherd (2005). Moreover, all items used five-point of Likert scale bring the means $1=$ strongly disagree, $2=$ disagree, $3=$ neither disagree nor agree, $4=$ agree and $5=$ strongly agree.

Besides that, the mediating variables were access to finance and competitive advantage. The first mediating variable is access to finance (ATF) constructed by nine items (ATF1 - ATF9) demonstrating the level of access to external financial sources. All items were transformed in form of composite scale amalgamated all items in the similar construct into one single observed variable (Hair et al., 2014). The measurement depicted as follow: $2=$ irregular, 3= medium, 4= regular and 5= highly regular, modified from past studies such as Fatoki (2012), Mason, Floreani, Miani, Beltrame, and Cappelletto (2015), Oni, Paiko and Ormin (2012) and Zampetakis et al. (2011). Next, the second mediating variable is competitive advantage (CA) where derived as second order construct of differentiation (DIFF), focus (FOCUS) and cost (COST) modified by Altintas, Kilic, Senol, and Isin (2010), Chan (2015), Chaiprasit and Swierczek (2011), Cousins (2015), and Meredith, McCutcheon, and Hartley (2014). Again, all items anchored to the scale of $1=$ strongly disagree, $2=$ disagree, $3=$ neither disagree nor agree, $4=$ agree and $5=$ strongly agree.

\section{Data Analysis}

The study follows Prajogo (2007) and Hair et al. (2014) by the means two-step process of separating the measurement model from the structural model. The process of data analysis started with Confirmatory Factor Analysis (CFA), followed by validity assessment, reliability assessment, multicollinearity assessment and normality assessment before the study carry on Structural Equation Model (SEM).

\section{Confirmatory Factor Analysis (CFA)}

The CFA procedures started by checked the factorial structure each of the construct (Alegre, Lapiedra, \& Chiva, 2006) when the items with a factor loading below 0.70 for existing scale was first deleted in the model (Mueller \& Hancockang, 2010). Then, this process should be continual in anticipation of the unidimensionality value requirement is achieved. According to Hair et al. (2014), the model goodness-of-fit is completed by counting at least one index from each category of absolute fit, incremental fit and parsimonious fit. Ultimately, 30 items out of 39 items were retained in the measurement model. Nine items namely; INNO1, RISK2, 
AC3, AC5, FOCUS4, FOCUS5, BP2, BP4 and BF7 were deleted in the measurement model to produce measurement model fit. Last measurement model fit indicates the following indices: $X^{2}=1413.259, d f=417, X^{2} / d f=2.784, N F I=0.933, T L I=0.971, C F I=0.987, R M S E A=0.059 ;$ where satisfied and achieved at least one category of goodness-of-fit: $X^{2} / d f<3.0, N F I>0.90, T L I>$ $0.90, C F I>0.90, R M S E A<0.08$.

\section{Validity and Reliability Assessment}

After measurement model achieved the goodness-of-fit indices, this present study performed validity and reliability assessment: convergent validity, discriminant validity, internal reliability and construct reliability (Montoya-Weiss \& Calantone, 1994) afore conducting structural model.

Convergent validity is achieved when Average Variance Extracted (AVE) values for all constructs depicted higher than 0.50 (range from 0.68 to 0.74 ) as suggested by Mueller and Hancock (2010). As well, the test of discriminant validity also satisfied where the square root of AVE value demonstrates greater than the values of correlation between particular constructs for all constructs (see Hair et al., 2014; Koufteros, Vonderembse, \& Doll, 2001; Lu, Lai, \& Cheng 2006).

Consequently, internal reliability for all constructs in this study also meet requirement where Cronbach's Alpha value is ranged between 0.87 and 0.923 resulting greater than 0.70 as underlined by Chang et al., (2007) and Hair et al., (2014). For the meantime, this study also completed construct reliability (CR) assessment since all constructs depicts $C R$ value greater than 0.60 as recommended by the rule of thumb (Hair et al., 2014).

Multicollinearity Assessment

Besides validity and reliability assessment, this study also confirmed that no multicollinearity issue exist by referring value of correlation between each pair of latent exogenous construct. The result in this research shows all value are less than 0.85 following the study by Ahmad, Ramayah, Wilson, and Kummerow (2010) and Alegre et al. (2006).

\subsubsection{Normality Assessment}

Similarly, this study also satisfied the normality distribution of the data before carry on structural model. The skewness of the data displays lower than 1.5 and critical ratio (C.R.) is lower than 8.0 (refer George \& Mallery, 2010). Moreover, the model was accepted for further analysis since 284 samples of this study also adequate to meet the assumption of using SEM analysis where size of sample (n) had better greater than 200 (see Hair et al., 2014; Sekaran \& Bougie, 2013; Zainudin, 2015).

\section{Structural Model and Hypothesis Testing}

In order to test the formulated hypotheses, the study replaced all covariance arrows into one-way arrow by the mean of convert the measurement model into structural model as in Figure 1. 


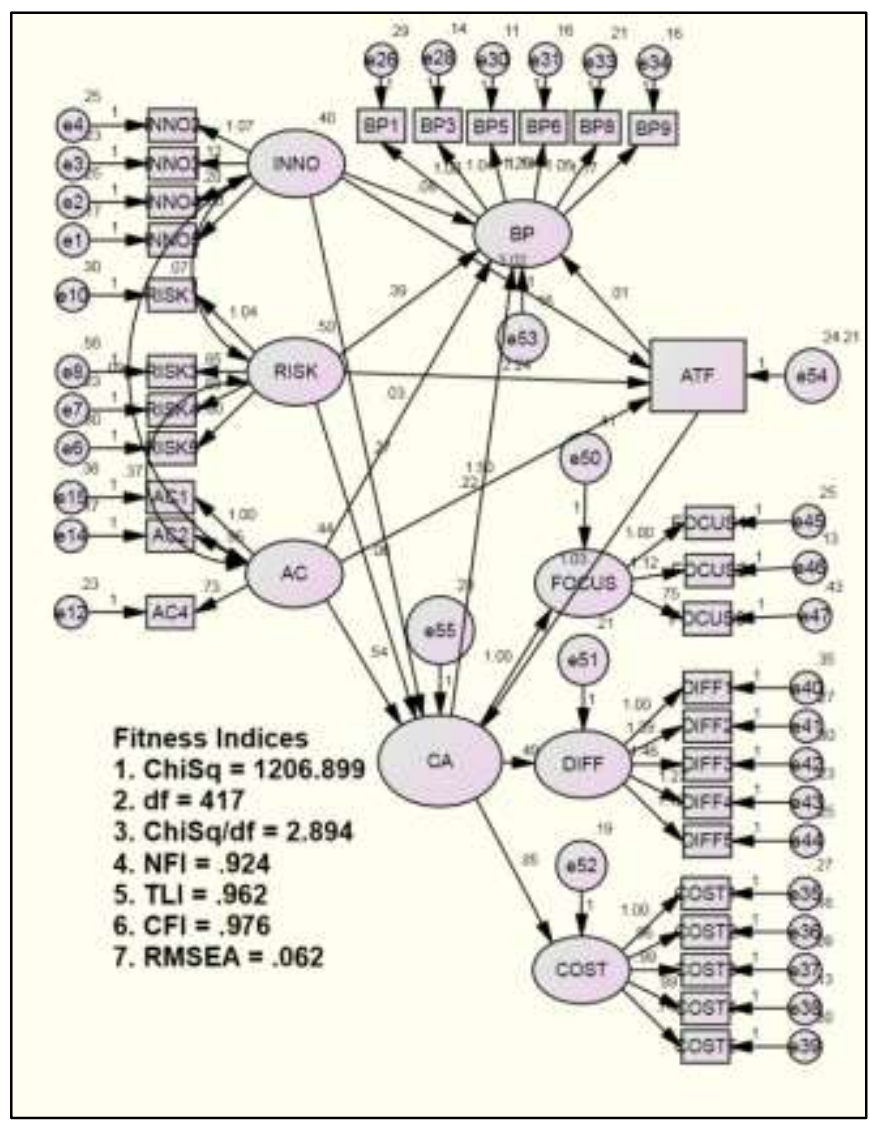

Notes: 1) CA is second order construct; 2) ATF is observed variable (Source: Based on AMOS Graphic developed by researchers for this study) Figure 1. Structural Model

Henceforward, the findings of $\mathrm{H} 1$ to $\mathrm{H} 2$ testing including sub-hypotheses $(\mathrm{H} 1 \mathrm{a}, \mathrm{H} 1 \mathrm{~b}$, $\mathrm{H} 1 \mathrm{c}, \mathrm{H} 2 \mathrm{a}, \mathrm{H} 2 \mathrm{~b}$ and $\mathrm{H} 2 \mathrm{c}$ ) are portrayed as in Table 2. As can be seen, utmost all tested paths are significantly in result.

Table 2. Hypotheses testing

\begin{tabular}{lclccc}
\hline & Path & & Estimate & P-value & Result \\
\hline INNO & $--->$ & BP & $\mathbf{0 . 0 7 8}$ & $\mathbf{0 . 0 3 9}$ & Significant \\
RISK & $--->$ & BP & $\mathbf{0 . 3 9 4}$ & $* * *$ & Significant \\
AC & $--->$ & BP & $\mathbf{0 . 0 2 9}$ & $\mathbf{0 . 0 4 4}$ & Significant \\
INNO & $--->$ & ATF & $\mathbf{3 . 0 2 4}$ & $* * *$ & Significant \\
RISK & $--->$ & ATF & $\mathbf{2 . 2 3 9}$ & $\mathbf{0 . 0 2 5}$ & Significant \\
AC & $--->$ & ATF & 1.505 & 0.171 & Not Significant \\
ATF & $--->$ & CA & $\mathbf{1 . 0 2 7}$ & $\mathbf{0 . 0 0 2}$ & Significant \\
CA & $--->$ & BP & $\mathbf{0 . 2 1 9}$ & $\mathbf{0 . 0 0 1}$ & Significant \\
\hline
\end{tabular}

Notes: 1) Highlighted row means path is significant. 2) *** Correlation is significant at 0.001 level (1-tailed).

Source: Based on AMOS Output developed by researchers for this study.

H1 was fully supported by the study since all dimensions of entrepreneurial orientation: innovativeness $(\mathrm{H} 1 \mathrm{a})$, risk taking $(\mathrm{H} 1 \mathrm{~b})$ and aggressive competitiveness $(\mathrm{H} 1 \mathrm{c})$ had 
positive significant relationship with SME performance. Specifically, innovativeness and aggressive competitiveness were significantly positive at level of 0.05 , while risk taking significant at 0.001 level.

In order to test serial mediation effect as formulated in $\mathrm{H} 2, \mathrm{H} 2 \mathrm{a}, \mathrm{H} 2 \mathrm{~b}$ and $\mathrm{H} 2 \mathrm{c}$, this study continue mediation testing followed procedures as underlined by Baron and Kenny (1986), Hair et al. (2014), Hayes (2013) and Zainudin (2015). The details procedures are depicted in Table 3.

Table 3. Serial mediation test procedures

\begin{tabular}{|c|c|c|c|c|}
\hline Path & Estimate & P-Value & $\begin{array}{c}\text { Result } \\
\left(a_{1} d_{1} b_{2}>c^{\prime}\right)\end{array}$ & Conclusion \\
\hline $\begin{array}{l}\text { Direct effect }\left(c^{\prime}\right): \text { INNO } \rightarrow \\
\text { BP }\end{array}$ & 0.078 & $\begin{array}{c}0.039 \\
\text { (Significant) }\end{array}$ & \multirow{5}{*}{$\begin{array}{c}\text { Total } \\
\text { indirect } \\
\text { effect }> \\
\text { direct effect } \\
= \\
0.680>0.078\end{array}$} & \multirow{5}{*}{$\begin{array}{c}\text { Partial } \\
\text { Mediation }\end{array}$} \\
\hline $\begin{array}{l}\text { Indirect effect: } \\
\text { INNO } \rightarrow \operatorname{ATF}\left(a_{1}\right)\end{array}$ & 3.024 & $\begin{array}{c}* * * \\
\text { (Significant) }\end{array}$ & & \\
\hline $\mathrm{ATF} \rightarrow \mathrm{CA}\left(d_{1}\right)$ & 1.027 & $\begin{array}{c}0.002 \\
\text { (Significant) }\end{array}$ & & \\
\hline $\mathrm{CA} \rightarrow \mathrm{BP}\left(b_{2}\right)$ & 0.219 & $\begin{array}{c}0.001 \\
\text { (Significant) }\end{array}$ & & \\
\hline $\begin{array}{l}\text { Total Indirect effect } \\
\left(a_{1} d_{1} b_{2}\right): \\
3.024 \times 1.027 \times 0.219\end{array}$ & 0.680 & (Significant) & & \\
\hline $\begin{array}{l}\text { Direct effect }\left(c^{\prime}\right): \text { RISK } \rightarrow \\
\text { BP }\end{array}$ & 0.394 & $\begin{array}{c}* * * \\
\text { (Significant) }\end{array}$ & \multirow{5}{*}{$\begin{array}{c}\text { Total } \\
\text { indirect } \\
\text { effect }> \\
\text { direct effect } \\
= \\
0.504>0.394\end{array}$} & \multirow{5}{*}{$\begin{array}{l}\text { Partial } \\
\text { Mediation }\end{array}$} \\
\hline $\begin{array}{l}\text { Indirect effect: } \\
\text { RISK } \rightarrow \operatorname{ATF}\left(a_{1}\right)\end{array}$ & 2.239 & $\begin{array}{c}0.025 \\
\text { (Significant) }\end{array}$ & & \\
\hline $\mathrm{ATF} \rightarrow \mathrm{CA}\left(d_{1}\right)$ & 1.027 & $\begin{array}{c}0.002 \\
\text { (Significant) }\end{array}$ & & \\
\hline $\mathrm{CA} \rightarrow \mathrm{BP}\left(b_{2}\right)$ & 0.219 & $\begin{array}{c}0.001 \\
\text { (Significant) }\end{array}$ & & \\
\hline $\begin{array}{l}\text { Total Indirect effect } \\
\left(a_{1} d_{1} b_{2}\right): \\
2.239 \times 1.027 \times 0.219\end{array}$ & 0.504 & (Significant) & & \\
\hline $\begin{array}{l}\text { Direct effect }\left(c^{\prime}\right): A C \rightarrow \\
B P\end{array}$ & 0.029 & $\begin{array}{c}0.044 \\
\text { (Significant) }\end{array}$ & \multirow{5}{*}{$\begin{array}{c}\text { Not } \\
\text { mediator } \\
\text { since } a_{1} \text { not } \\
\text { significant }\end{array}$} & \multirow{5}{*}{$\begin{array}{c}\text { No } \\
\text { Mediation }\end{array}$} \\
\hline Indirect effect: & & 0.171 & & \\
\hline $\mathrm{AC} \rightarrow \operatorname{ATF}\left(a_{1}\right)$ & 1.505 & $\begin{array}{c}\text { (Not } \\
\text { Significant) }\end{array}$ & & \\
\hline $\mathrm{ATF} \rightarrow \mathrm{CA}\left(d_{1}\right)$ & 1.027 & $\begin{array}{c}0.002 \\
\text { (Significant) }\end{array}$ & & \\
\hline $\mathrm{CA} \rightarrow \mathrm{BP}\left(b_{2}\right)$ & 0.219 & $\begin{array}{c}0.001 \\
\text { (Significant) }\end{array}$ & & \\
\hline
\end{tabular}

Note: ${ }^{* * *}$ Correlation is significant at 0.001 levels (1-tailed).

Source: Based on AMOS Output developed by researchers for this study. 
The mediating effect was determined by comparing the direct effect and indirect effect of the structural paths (refer Baron \& Kenny, 1986; Hair et al., 2014; Hayes, 2013). As depicted in Table 3, $\mathrm{H} 2$ was partially supported by the study since $\mathrm{H} 2 \mathrm{a}$ and $\mathrm{H} 2 \mathrm{~b}$ were partially supported, while $\mathrm{H} 2 \mathrm{c}$ was not supported. Resulting this, the relationship between entrepreneurial orientation and SME performance is serially partial mediated by the access to finance and competitive advantage. Particularly, the study confirmed that the relationship of innovativeness, risk taking and SME performance were partially serial mediated by the access to finance and competitive advantage. In contrast, no mediation was found in $\mathrm{H} 2 \mathrm{c}$ due to insignificant path between aggressive competitiveness and access to finance ( $A C \rightarrow A T F)$, lead to violated requirement of the mediating procedure as underlined.

\section{Results and Discussions}

As shown in Table 4, almost 65 per cent of the sample were male entrepreneurs (63\%) compared to women entrepreneurs. Moreover, almost 80 per cent of them were aged between 21 to 50 years old, concluded that the majority of the SMEs owners in this study areas come from middle-age group. Furthermore, 54.6 per cent of selected entrepreneurs at least completed their secondary educational level which brings the mean of attended form 1 to 5; meanwhile, in contrast less than 2 per cent exposed they were school dropout and foreign educational certificated holders. The rest of them were completed post-secondary and tertiary education, 29.9 per cent and 14.1 per cent respectively. Judging from this, this current study concluded that the respondents have basic knowledge of competencies where they at least capable to reading and writing. Quite interesting, the facts of findings also depicts that utmost 70 per cent of them actually have greater than 10 years of prior business experiences.

In term of enterprises profile of the sample, the result of present study indicates 72.9 per cent of SMEs were offering services sectors which is they were involving in operation of restaurant, wholesale, laundry, workshop, accommodation, beauty center, communication, retail business, stitches, professional, transportation and storage, as well. Besides that, majority of the enterprises recorded the business have been operated since 3 to 10 years ago. Based on the age ranged, this study could summarise that most of them were in growth stage referring to Business Life Cycle theory as developed by Churchill and Lewis (1983). However, Zhu (2006) reminded that the duration of the growth stage, as all the other stages, depends on the type of industry or product line of operating business. Even so, 95 per cent of them come from small size compared to medium size as judging from the number of full-time employees (employed between 5 and 18 workers). Probability due to majority of them was small enterprises, 85.6 percent of the business owners were managing individual proprietorship business. 
Table 4: Demographic profile of sample

\begin{tabular}{|c|c|c|c|}
\hline Variables & & $\begin{array}{c}\text { Frequency } \\
(n=284)\end{array}$ & $\begin{array}{c}\text { Percentage } \\
(\mathbf{1 0 0 . 0 \% )}\end{array}$ \\
\hline \multirow[t]{2}{*}{ Gender } & Male & 179 & 63.0 \\
\hline & Female & 105 & 37.0 \\
\hline \multirow[t]{5}{*}{ Age (years old) } & $21-30$ & 37 & 13.0 \\
\hline & $31-40$ & 90 & 31.7 \\
\hline & $41-50$ & 96 & 33.8 \\
\hline & $51-60$ & 52 & 18.3 \\
\hline & $>60$ & 9 & 3.2 \\
\hline \multirow[t]{5}{*}{ Educational Level } & Primary & 1 & 0.4 \\
\hline & Secondary & 155 & 54.6 \\
\hline & $\begin{array}{l}\text { Post- } \\
\text { secondary }\end{array}$ & 85 & 29.9 \\
\hline & Tertiary & 40 & 14.1 \\
\hline & $* *$ Others & 3 & 1.0 \\
\hline Business & $1-3$ & 11 & 3.9 \\
\hline Experiences & $4-6$ & 47 & 16.5 \\
\hline \multirow[t]{2}{*}{ (years) } & $7-9$ & 32 & 11.3 \\
\hline & $\geq 10$ & 194 & 68.3 \\
\hline Business & Services & 207 & 72.9 \\
\hline \multirow[t]{3}{*}{ Activities } & Manufacturing & 53 & 18.7 \\
\hline & Construction & 11 & 3.9 \\
\hline & Agricultural & 13 & 4.6 \\
\hline \multirow[t]{3}{*}{ Firm Age (years) } & $3-6$ & 90 & 31.7 \\
\hline & $7-10$ & 89 & 31.3 \\
\hline & $>10$ & 105 & 37.0 \\
\hline No. of Fulltime & $5-18$ & 269 & 94.7 \\
\hline \multirow[t]{4}{*}{ Employees } & $19-32$ & 4 & 1.4 \\
\hline & $33-46$ & 7 & 2.5 \\
\hline & $47-60$ & 0 & 0 \\
\hline & $61-74$ & 4 & 1.4 \\
\hline \multirow[t]{2}{*}{ Ownership Types } & $\begin{array}{l}\text { Sole- } \\
\text { proprietorship }\end{array}$ & 243 & 85.6 \\
\hline & Partnership & 41 & 14.4 \\
\hline
\end{tabular}

Source: Based on Data Output developed by researchers for this study.

The key findings based on results of hypothesis testing (refer Table 2) confirmed that entrepreneurial orientation was positive significant influenced to SME performance. To Lumpkin and Dess (1996) mentioned a resilient entrepreneurial orientation at firm level could influence the achievement of better performance. Besides that, entrepreneurial orientation has positive relationship to business performance in circumstance they sustain in a competitive environment (Barringer \& Bluedom, 1999).

Moreover, since entrepreneurial orientation come from multi-dimensional constructs, three dimensions of entrepreneurial orientation: innovativeness, risk taking and 
aggressive competitiveness were fully supported by this current study. Subsequently, this study in lined with numerous prior studies such as Alejandro (2015), Awang et al. (2010), Esteve, Peinoda, and Peinado (2009), Lumpkin and Dess (1996), Lumpkin, Brigham, and Moss (2010), Roxas (2009) and Wiklund and Shepherd (2005). This study agreed the organization with innovativeness may open source of ideas that leads to development and therefore profited in nourishing a competitive company which vital for enduring sustainability in the industry (Lumpkin, Brigham, \& Moss, 2010). Furthermore, the firm willing to take calculated risk was and able to manage risk by reducing the risk exposure could promise to better business performance (Willebrands, Lammers, \& Hartog, 2012). Meanwhile, organization with high of aggressive competitiveness is believed can directly challenge their competitors and passionately in attaining a competitive position which bring the firm to greater business performance (Shehu \& Mahmood, 2014).

Besides the direct path, this study also connected the serial mediating effect of access to finance and competitive advantage in the relationship between entrepreneurial orientation and SME performance based on RBV theory framework. The results from this study portrayed partially agreed where innovativeness and risk taking in the firm level could improve level of access to external finance and support the competitive advantage which ultimately influenced on business performance as debated in various past studies (e.g. Morgan, Anokhin, \& Wincent, 2016; Al-Mamun et al., 2018; Chew, 2018; Mazida et al., 2018).

Contrast with other studies, aggressive competitiveness at the firm level was irrelevant in open up more chances for entrepreneurs to have better access on external financial sources as prior expectation since the result shows insignificant paths between them. Therefore, this research was not supported the earlier scholars for instance Fatoki (2012), Ibrahim and Shariff (2015), Ogunsiji and Ladanu (2010), Wiklund and Shepherd (2005), and Zampetakis et al. (2011). However, little access of external financial sources were not solely depended on firm characteristics but also influenced by other factor such as dynamic changes in environment (Frank et al., 2010), macro-economy situation, issues of crime and corruption, ethical perceptions and legal environment (Fatoki \& Smit, 2011).

The question rose here, why this study was not fully supported the early prediction as formulated in the stated hypotheses. However, Wiklund and Shepherd (2005) reminded that a diverse in findings potentially because of the comparison the configuration result which may lead to different in perspectives of entrepreneurial orientation on business performance impact (Frank, Kess, \& Fink, 2010). In addition, Rauch and Frese (2009) opined that entrepreneurial orientation effect may differ across the countries subsequently dissimilarities in characteristics and cultural (Naldi, Nordqvist, Sjöberg, \& Wiklund, 2007; Mueller \& Thomas, 2001). To Lechner and Gudmundson (2014), performance of the firm was dissimilar accordance on implementation of entrepreneurial orientation individually. Besides that, Fernández, Montes, and Vazquez (2000) also stated that competitive advantage, nevertheless, in several circumstances become challenges to be categorised and recognised.

\section{Conclusion}

The main aim of this study is examining the relationship between entrepreneurial orientation and SME performance. This current work also objectively to advance prior studies by determine the serial mediation effect of access to finance and competitive advantage as mediators in the relationship between entrepreneurial orientation and SME business performance. As a result, the key findings of the study underlined three dimensions of 
entrepreneurial orientation: innovativeness, risk taking and aggressive competitiveness were significantly positive influence to SME performance. In advance, this study also tested serial mediation effect, where access to finance and subsequently, competitive advantage were partially confirmed as serial mediators in the relationship of innovativeness, risk taking and SME performance. However, no mediation effect found between aggressive competitiveness and SME performance. The results concluded that the important of entrepreneurial orientation as an essential tool for exploring and exploiting financing opportunities, thus, supporting competitive advantage and ultimately influence to better business performance. Besides that, this study could remind those policy makers and other support systems to develop more systematic and comprehensive systems that emphasize on the importance of entrepreneurship activities where high of entrepreneurial orientation in firm level possibly will lead to better chances for external financing, then support competitive strategies in firm and in the end improving their overall business performance.

Overall this study aims to consolidate the RBV theory; the firm with strategic resources and capabilities may contribute to competitive advantage, while, competitive advantage is impact to firm performance. Moreover, this research also expands the literatures of respective fields and extends the current understanding of the determinants of business performance. Last but not least, the findings remind the authorities for instances policy makers, support systems as well as entrepreneurs, the important of entrepreneurial orientation and access to external financial resource which could offer competitive advantage in the firm which to conclude enhance business performance.

\section{Limitations and Future Directions}

Instead of glowing impact of the study, there are some constraints that can be improved by future research. Firstly, this study only focused on SMEs in Malaysia context, which leads difficulty to the current study generalize its findings, due to the framework of this study was emphasis in the local scale. So, the researchers propose to apply similar framework on SMEs in other countries. Moreover, the future studies also may conduct a comparative study between these countries in order to increase result generalization.

Secondly, this study only put attention on entrepreneurial orientation, access to finance and competitive advantage as the internal and external sources and capabilities as taxonomy of RBV theory which influenced on business performance changes. Meanwhile, there were other various internal or external sources and capabilities in determining the business performance variation. Henceforth, future works should consider to exploratory and take into account more crucial factors that relevant to the variation of business performance to advance this present study.

Thirdly, last but not least, this current study was mainly depended on quantitative approach. Since it focused on quantitative design, the data primarily come from selfadministered and face-to-face survey which may incline to data biasness might be because enumerators may purposely by mistake took those who are easy to contact, easy-to-approach or non-threatening respondents (see Doherty, 1994) where could jeopardise the collected data. Therefore, in order to improve the research methodology, the study recommends the next researchers to employ qualitative approach which could provide deep sufficient perspectives compared to this study. 


\section{References}

Ahmad, N. H., Ramayah, T., Wilson, C., \& Kummerow, L. (2010). Is entrepreneurial competency and business success relationship contingent upon business environment? A study of Malaysian SMEs. International Journal of Entrepreneurial Behaviour \& Research, 16 (3), 182-203.

Alegre, J., Lapiedra, R., \& Chiva, R. (2006). A measurement scale for product innovation performance. European Journal of Innovation Management, 9 (4), 333-346.

Alejandro, R. V. (2015). Leadership Style, Entrepreneurial Orientation and Innovation: The Impact on Business Performance and Competitiveness in Puerto Rico (Doctoral dissertation). Available from ProQuest Dissertations and Theses database. (UMI No.: 3709292)

Al-Mamun, A., Mohiuddin, M., Fazal, S. A., \& Ghazali, A. (2018). Effect of entrepreneurial and market orientation on consumer engagement and performance of manufacturing SMEs. Management Research Review, 41 (1), 133-147.

Altintas, M. H., Kilic, S., Senol, G., \& Isin, F. B. (2010). Strategic objectives and competitive advantages of private label products: Manufacturers' perspective. International Journal of Retail \& Distribution Management, 38 (10), 773-788.

Andersén, J. (2010). A critical examination of the EO-performance relationship. International Journal of Entrepreneurial Behaviour \& Research, 16 (4), 309-328.

Ar, I. M., \& Baki, B. (2011). Antecedents and performance impacts of product versus process innovation: empirical evidence from SMEs located in Turkish science and technology parks. European Journal of Innovation Management, 14 (2), 172-206.

Avlonitis, G. J., \& Salavou, H. E. (2007). Entrepreneurial orientation of SMEs, product innovativeness, and performance. Journal of Business Research, 60, 566-575.

Awang, A., Ahmad, Z. A., Asghar, A. R. S., \& Subari, K. A. (2010). Entrepreneurial orientation among Bumiputera Small and Medium Agro-Based Enterprises (BSMAEs) in West Malaysia: Policy implication in Malaysia. International Journal of Bussiness and Management, 5 (5), 13- 143.

Awino Z. B., \& Kariuki, P. M. (2012). Firm strategy, business environment and the relationship between firm level factors and performance. DBA Africa Management Review, 2 (1), 77-98.

Ayyagari, M., Demirguc-Kunt, A., \& Maksimovic, V. (2011). Small vs. Young Firms across the World: Contribution to Employment, Job Creation, and Growth. Policy Research Working

Paper No. 5631. Retrieved from: http://www-
wds.worldbank.org/servlet/WDSContentServer/WDSP/IB/2012/11/06/000158349_20 121106091157/Rendered/PDF/WPS5631.pdf

Barney, J. (1986). Strategic factor markets: Expectations, luck and business strategy. Management Science, 32 (10), 1231-1241.

Baron, R. M., \& Kenny, D. A. (1986). The moderator-mediator variable distinction in social psychological research: conceptual, strategic, and statistical considerations. Journal of Personality and Social Psychology, 51 (6), 1173-1182.

Barrett, M., Davidson, E., Prabhu, J., \& Vargo, S. L. (2015). Service innovation in the digital age: key contributions and future directions. MIS Quarterly: Management Information Systems, 39 (1), 135-154. 
Barringer, B. R., \& Bluedorn, A. C. (1999). The relationship between corporate entrepreneurship and strategic management. Strategic Management Journal, 20, 421-444.

Bernama. (2017, March 30). Rahim: Failure rate among Bumi entrepreneurs still high. Retrieved

from: http://www.freemalaysiatoday.com/category/nation/2017/03/30/rahimfailure-rate-among-bumi-entrepreneurs-still-high/

Blackburn, R. A., Hart, M., \& Wainwright, T. (2013). Small business performance: business, strategy and owner-manager characteristics. Journal of Small Business and Enterprise Development, 20 (1), $8-27$.

Casillas, J. C., Moreno, A. M., \& Barbero, J. L. (2011). Entrepreneurial orientation of family firms: Family and environmental dimensions. Journal of Family Business Strategy, 2 (2), 90-100.

Castellaneta, F. (2016). Building firm capability: managerial incentives for top performance. Journal of Business Strategy, 37 (4), 41-46.

Chahal, H., \& Bakshi, P. (2015). Examining intellectual capital and competitive advantage relationship: Role of innovation and organizational learning. International Journal of Bank Marketing, 33 (3), 376-399.

Chaiprasit, S., \& Swierczek, F. W. (2011). Competitiveness, globalization and technology development in Thai firm. Competitiveness Review: An International Business Journal, 21 (2), 188-204.

Chan, J. W. K. (2015). Competitive strategies and manufacturing logistics: An empirical study of Hong Kong manufacturers. International Journal of Physical Distribution \& Logistics Management, 35 (1), 20-43.

Chang, S. C., Lin, R. J., Chang, F. J., \& Chen, R. H. (2007). Achieving manufacturing flexibility through entrepreneurial orientation. Industrial Management \& Data Systems, 107 (7), 997-1017.

Chew, T. C. (2018). The effects of cultural dimensions, government regulations and entrepreneurial orientation on firms' international performance: A study of SMEs in Malaysia (PhD thesis). University of Glasgow. Retrieved from: http://encore.lib.gla.ac.uk/iii/encore/record/C_Rb3300235

Churchill, N. C., \& Lewis, V. L. (1987). The five stages of small business growth. Harvard business review, 3 (3). Retrieved from: https://hbr.org/1983/05/the-five-stages-ofsmall-business-growth

Cooper, D., \& Schindler, P. (2014). Business research methods (12th ed.). USA: McGraw Hill Education.

Cousins, P. D. (2015). The alignment of appropriate firm and supply strategies for competitive advantage. International Journal of Operations \& Production Management, 25 (5), 403-428.

Covin, G., \& Slevin, D. (1989). Strategic management of small firms in hostile and benign environments. Strategic Management Journal, 10 (1), 75-87.

Covin, J. G., Green, K. M., \& Slevin, D. P. (2006). Strategic process effects on the entrepreneurial orientation - sales growth rate relationships. Entrepreneurship Theory and Practice, 30 (1), 57-81.

Doherty, M. (1994). Probability versus Non-Probability Sampling in Sample Surveys. The New Zealand Statistics Review, March 1994, 21-28. 
DOS Malaysia. (2018). Profile of Small and Medium Enterprise. ISBN 978-983-9044-67-6. Retrieved from:

https://www.dosm.gov.my/v1/index.php?r=column/cone\&menu_id=T2pLUVNDNFh 2UGw5azJvYzRJOWFMZz09

Esteve, E. A., Peinoda, S. A., \& Peinado, S. E. (2009). The influence of top management teams in the strategic orientation and performance of Small and Medium-sized Enterprises. British Journal of Management, 20, 581-559.

Fatoki, O. (2012). The Impact of Entrepreneurial Orientation on Access to Debt Finance and Performance of Small and Medium Enterprises in South Africa. Journal Social Science, 32(2), 121-131.

Fatoki, O. O., \& Smit, A. V. A. (2011). Constraints to credit access by new SMEs in South Africa: A supply-side analysis. African Journal of Business Management, 5 (4), 1413.

Fernandez, E., Montes, J. M., \& Vazquez, C. J. (2000). Topology and Strategic Analysis of Intangible Resources: A Resource-based Approach, Technovation, 20, 81-92.

Frank, H., Kessler, A., \& Fink, M. (2010). Entrepreneurial Orientation and Business Performance - A Replication Study. Schmalenbach Business Review, 62, 175-198.

Gathenya, J. W., Bwisa, H. M., \& Kihoro, J. M. (2011). Interaction between women entrepreneurs' age and education on business dynamics in Small and Medium Enterprises in Kenya. International Journal of Business and Social Science, 2 (15), 265272.

George, D., \& Mallery, M. (2010). SPSS for windows step by step: A simple guide and reference, 17.0 update (10 ed.). Boston: Pearson.

Hair, J. F., Black, W. C., Babin, B. J., \& Anderson, R. E., (2014). Multivariate data analysis (7th ed.). New Jersey: Pearson Prentice-Hall.

Hansen, J. D., Deitz, G. D., Tokman, M., Marino, L. D., \& Weaver, K. M. (2011). Cross-national invariance of the entrepreneurial orientation scale. Journal of Business Venturing, 26 (1), 61-78.

Hayes, A. F. (2013). Introduction to mediation, moderation, and conditional process analysis: A regression-based approach. New York, NY: The Guilford Press.

Henard, D. H., \& McFadyen, M. A. (2012). Resource dedication and new product performance: A Resource-Based view. Journal of Product Innovation Management, 29 (2), 193-204.

Hermann, F., Kessler, A., \& Fink, M. (2010). Entrepreneurial orientation and business performance-a replication study. Schmalenbach Business Review, 62 (2), 175-198.

Ibrahim, M. A., \& Mohdshariff, M. N. (2015). Mediating Role of Access to Finance on the Relationship between Strategic Orientation Attributes and Small Medium Enterprises (SMEs) Performance in Nigeria. Proceedings of 3rd International Conference on Rural Development and Entrepreneurship, (pp. 91-102).

Jarvis, P. (2015, December 9). 8 Out Of 10 Statistics Are Completely Made Up. Retrieved from: https://pjrvs.com/stats/

Jeff, D. (2017, August 2). Why Do Businesses Fail? Retrieved from: http://www.businessinsider.com/why-small-businesses-fail-infographic-20178/?IR=T

Davis, J., Greg Bell, R., Tyge Payne, G., \& Kreiser, P. (2010). Entrepreneurial Orientation and Firm Performance: The Moderating Role of Managerial Power, American Journal of Business, 25 (2), $41-54$. 
Kellermanns, F. W., \& Eddleston, K. A. (2006). Corporate entrepreneurship in family firms: A family perspective. Entrepreneurship Theory and Practice, 30 (6), 809-830.

Kenny, D. A., Kaniskan, B., \& McCoach, D. B. (2011). The performance of RMSEA in models with small degrees of freedom. Unpublished paper, University of Connecticut.

Knight, G. A. (1997). Cross-cultural reliability and validity of a scale to measure firm entrepreneurial orientation. Journal of Business Venturing, 12 (3), 213-225.

Koe, W. L. (2013). Entrepreneurial orientation (EO) and performance of Government-Linked Companies (GLCs). Journal of Entrepreneurship, Management and Innovation, 9 (3), 21-41.

Koufteros, X. A., Vonderembse, M. A., \& Doll, W. J. (2001). Concurrent engineering and its consequences. Journal of Operations Management, 19 (1), 97-115.

Kreiser, P. M., Marino, L. D. \& Weaver, K. M. (2002). Reassessing the environment-EO link: the impact of environmental hostility on the dimensions of entrepreneurial orientation. Academy of Management Proceedings, 71-76.

Krejcie, R. V., \& Morgan, D.W. (1970). Determining sample size for research activities. Educational and Psychological Measurement, 30, 607-610.

Kuratko, D., Ireland, D., Covin, J., \& Hornsby, J. (2005). A model of middle-level managers' entrepreneurial behaviour. Entrepreneurship, Theory and Practice, 13 (4), 62-72.

Lechner, C., \& Gudmundson, S. V. (2014). Entrepreneurial orientation, firm strategy and small firm performance. International Small Business Journal: Researching Entrepreneurship, 32 (1), $36-60$.

Li, Y., Zhao, Y., Tan, J., \& Liu, Y. (2008). Moderating effects of entrepreneurial orientation on market orientation performance linkage: Evidence from Chinese small firms. Journal of Small Business Management, 46 (1), 113-133.

Lorenzo, J. R., Rubio, M. T., \& Garcés, S. A. (2018). The competitive advantage in business, capabilities and strategy. What general performance factors are found in the Spanish wine industry? Wine Economics and Policy, 1 (4), 1 -15.

Lu, C. S., Lai, K. H., \& Cheng, T. C. E. (2006). Application of structural equation modeling to evaluate the intention of shippers to use Internet services in liner shipping. European Journal of Operational Research, 180 (2), 845-867.

Lumpkin, G. T., Brigham, K. H., \& Moss, T. W. (2010). Long-term orientation: Implications for the entrepreneurial orientation and performance of family businesses. Entrepreneurship and Regional Development, 22(3-4), 241-264.

Lumpkin, G.T., \& Dess, G.G. (1996). Clarifying the entrepreneurial orientation construct and linking it to performance. The Academy of Management Review, 21 (1), 135-172.

Mahoney, J. 1995. The management of resources and the resource of management. Journal of Business Research, 33, 91-101.

Mason, M. C., Floreani, J., Miani, S., Beltrame, F., \& Cappelletto, R. (2015). Understanding the impact of entrepreneurial orientation on SMEs' performance: the role of the financing structure. Procedia Economics and Finance, 23, 1649-1661.

Mazida, I., Norhidayah, M., \& Salleh, Y. (2018). Strategic orientation and international firm performance: A pilot study of Malaysian SMEs halal product manufacturer. Advanced Science Letters, 24 (4), 2743-2745.

Meredith, K. R., McCutcheon, D. M., \& Hartley, J. (2014). Enhancing competitiveness through the new market value equation. International Journal of Operations \& Production Management, 14 (11), 7-22. 
Messeghem, K. (2003). Strategic entrepreneurship and managerial activities in SME. International Small Business, 21 (2), 197-212.

Miller, D. (1983). The correlates of entrepreneurship in three types of firms. Management science, 29 (7), 770-791.

Montoya-Weiss, M., \& Calantone, R. J. (1994). Determinants of new product performance: A review and meta-analysis. Journal of Product Innovation Management, 11 (5), 397417.

Moreno, A., \& Casillas, J. (2008). Entrepreneurial orientation and growth of SMEs: a causal model. Entrepreneurship Theory and Practice, 32 (3), 507-528.

Morgan, T., Anokhin, S., \& Wincent, J. (2016). Entrepreneurial orientation, firm market power and opportunism in networks. Journal of Business \& Industrial Marketing, 31 (1), 99111.

Mueller, R. O., \& Hancock, G. R. (2010). Structural Equating Modeling white book. Retrieved from: www.education.umd.edu/EDMS/fac/Hancock/SEM2page.html

Naldi, L., Nordqvist, M., Sjöberg, K., \& Wiklund, J. (2007). Entrepreneurial Orientation, Risk Taking, and Performance in Family Firms. Family Business Review, 20 (1), 33-47.

Ogunsiji, P. A. S., \& Ladanu, W. K. (2010). Entrepreneurial Orientation as a Panacea for the Ebbing Productivity in Nigerian Small and Medium Enterprises: A Theoretical Perspective. International Business Research, 3 (4), 192 -199.

Oni, E. O., Paiko, I. I., \& Ormin, K. (2012). Assessment of the contribution of Micro Finance Institutions (MFIs) to sustainable growth of Small and Medium Scale Enterprises (SMEs) in Nigeria. Interdisciplinary Journal of Contemporary Research in Business, 3 (9), 1099-1110.

Porter, M.E. (1980), Competitive strategy: Techniques for analysing industries and competitors. Free Press, New York: NY.

Prajogo, D. I. (2007). The relationship between competitive strategies and product quality. Industrial Management \& Data System, 107 (1), 69-83.

Rauch, A., \& Frese, M. (2009). Psychological approaches to entrepreneurial success: a general model and an overview of findings, in Cooper, C.L. and Robertson, I.T. (Eds), International Review of Industrial and Organisational Psychology, Wiley, Chichester, 101-142.

Rosli, M., \& Norshafizah, H. (2013). Entrepreneurial Orientation and Business Performance of Women-Owned Small and Medium Enterprises in Malaysia : Competitive advantage as a mediator. International Journal of Business and Social Science, 4 (1), 82-90.

Roxas, H. B. G. (2009). Institutions, Strategic Posture and the Performance of Micro, Small and Medium Enterprises, PhD Thesis, Victoria.University of Wellington, New Zealand.

Schans, K. (2012). SME Access to External Finance. BIS Economics Paper No. 16. Retrieved

from:

https://assets.publishing.service.gov.uk/government/uploads/system/uploads/attac hment_data/file/32263/12-539-sme-access-external-finance.pdf

Schilke, O. (2014). On the contingent value of dynamic capabilities for competitive advantage: the nonlinear moderating effect of environmental dynamism. Strategic Management Journal, 35 (2), 179-203.

Sekaran, U., \& Bougie, R. (2013). Research method for business: A skill building approach (6th ed.). United States: John Wiley \& Sons Inc. 
Shehu, A. M., \& Mahmood, R. (2014). Influence of Entrepreneurial Orientation and Business Environment on Small and Medium Firm Performance: A PLS Approach. Advances in Management \& Applied Economics, 4 (4), 101-114.

SME Annual Report. (2017/2018). Retrieved from:

http://www.smeinfo.com.my/index.php?option=com_content\&view=article\&id=141 $5 \&$ Itemid $=1312$ \&lang=en

SME Corporation Malaysia. (2019). Retrieved from: http://www.smeinfo.com.my/index.php/en/sme-definition/developing-malaysiansmes/importance-of-smes

Suhail, A. B., \& Mushtaq, A. D. (2016). Customer relationship management: An approach to competitive advantage in the banking sector by exploring the mediational role of loyalty. International Journal of Bank Marketing, 34 (3), 388-410.

Tambunan, T. T. (2011). Development of small and medium enterprises in a developing country: The Indonesian case. Journal of Enterprising Communities: People and Places in the Global Economy, 5 (1), 68-82.

Tarabishy, A., Solomon, G., Fernald, L. \& Saghkin, M. (2005). The entrepreneurial leader's impact on the organization's performance in dynamic markets. Journal of Equity, 8 (4), 20-29.

US Small Business Administration. (2017). Retrieved from: https://www.sba.gov/

Vance, P. S., \& Angelo, D. C. F. (2007). Reputação Corporativa: Uma Revisão Teórica. Revista de Gestão, 14 (4), 93-108.

Weismeier-Sammer, D. (2011). Entrepreneurial behavior in family firms: a replication study. Journal of Family Business Strategy, 2 (3), 128-138.

Wernerfelt, B. (1984). A resource-based view of the firm. Strategic Management Journal, 5, 171-180.

Wiklund, J., \& Shepherd, D. (2005). Entrepreneurial orientation and small business performance: a configurational approach. Journal of Business Venturing, 20 (1), 7189.

Willebrands, D., Lammers, J., \& Hartog, J. (2012). A successful businessman is not a gambler: risk attitude and business performance among small enterprises in Nigeria. Journal of Economic Psychology, 33 (2), 342-354.

Zahra, S. A., \& Covin, J. G. (1995). Contextual influences on the corporate entrepreneurship performance relationship: A longitudinal analysis. Journal of Business Venturing, 10 (3), 43-58.

Zainudin, A. (2015). SEM Made Simple: A gentle approach to learning structural equation modeling. Bangi, Selangor: MPWS Rich Publication.

Zampetakis, L. A., Vekini, M., \& Moustakis, V. (2011). Entrepreneurial orientation, access to financial resources, and product performance in the Greek commercial TV industry, The Service Industries Journal, 31(6), 897-910.

Zhu, W. (2006). Learning, Diffusion, and Industry Life Cycle, Federal Reserve Bank of Kansas City, Working Paper 04-01. Retrieved from: www.kansascityfed.org/PUBLICAT/PSR/RWP/NBER-WangPaper.pdf 15 January 2006. 